\title{
ARMENIAN MEDIEVAL PHILOSOPHY AND MEDICAL SCIENCE: NAREK AS A REMEDY
}

\begin{abstract}
This article is devoted to the scientific-philosophical analyses of the ideas of the $\mathrm{X}$ century outstanding Armenian mystical philosopher Gregory of Narek on objectification of the non-objective.
\end{abstract}

Keywords: spiritual remedy, sins, diseases, objectification of the non-objective.

From ancient times medication was considered to be a miracle, something that only magicians and those with supernatural powers could do. Hence a special reverence was conferred to those who mastered this unique trade.

Health is a divine grace. The human creature is made of both flash and spirit thus the term health applies to two entities: to body and to spirit. The disease was considered to be a chaotic condition of the body or spirit or both. Health was considered to be a harmony between the body and the mind. If a person was healthy it was believed that all parts of his/her body were in a harmony and order. The opposite is also true: if a person was ill, it was believed that his/her spirit was rebelling against his body or vice versa his/her body was fighting against the spirit. The disease was associated with chaos. Thus a person could pass from the domain of order and harmony to the domain of disorder and chaos.

It was also believed that there were two types of diseases: one physical and the other one spiritual (as against psychological). As there were two diseases, both spiritual and physical means of curing were stressed in the past (of Gregory of Narek 1970).

Spiritual health was considered to be akin to common sense to the capacity of healthy judgment. Only those, who have proper capacity of judgment, who have clear mind and aspire to be present have common sense and are spiritually healthy. To be spiritually healthy means to be peaceful. Those who are spiritually healthy can differentiate the truth and falsehood. The spiritually healthy people are empathetic and support their fellows in need. Spiritually healthy people, according to Narekatsi are those with strong faith, they are free from negative passions. Being spiritually healthy means being humanly perfect that is as perfect as a human can be. Spiritual health is ensured through repentance, holiness, with strong faith, hope, love and other virtues.

The book known as Narek was written by Gregory of Narek a monk from Eastern Armenia. Narek was written in 1001-1003 A.D. Gregory of Narek was a high rank priest who was both a very influential cleric as well as social/political figure of his time. Narek is an extensive prayer, composed of 95 parts and over 10000 lines none of which repeats the other. The prayer was highly valued in the middle ages and it was copied over and over numerous times. The Book of Narek, otherwise known as Book of Lamentation, is valued both for its artistic style and the important role it played among Armenians. Up to date thousands of Armenians maintain the belief that the book has a healing capacity and read it for the diseased.

Narek was written for both glorifying the Almighty and for curing spiritual and physical diseas- 
es. Each of the 95 parts of the "Book of Lamentation" cures one disease.

During the history specific lists have been created which specifically name the diseases each part (In Armenian Ban which means logos, word, and idea) cures. These lists also indicate the number of times each part needs to be read for observing its curing effect. In the introduction of the academic publication of Narek (Yerevan, 1985, pp. 158-168) five similar lists of remedies are presented. A. Petrosyan, a scholar of Narek, adds another list from the manuscript \# 8428 from the Matenadaran, the institute of Ancient manuscripts. This manuscript also indicates the number of times Narek needs to be read for attaining each of its curing effect (Petrosyan 2002. 58).

All 10000 lines are filled with love, the ultimate reverence towards the Almighty and with the consideration of human limitedness and sinfulness. The Book starts with the following lines:

The voice of a sighing heart, its sobs and mournful cries,

I offer up to you, O Seer of Secrets, placing the fruits of my wavering mind as a savory sacrifice on the fire of my grieving soul

to be delivered to you in the censer of my will. Compassionate Lord, breathe in this offering and look more favorably on it than upon a more sumptuous sacrifice offered with rich smoke. Please find this simple string of words acceptable.

Do not turn in disdain.

May this unsolicited gift reach you, this sacrifice of words from the deep mystery-filled chamber of my feelings, consumed in flames fueled by whatever grace I may have within me. As I pray, do not let these pleas annoy you, Almighty, like the raised hands of Jacob, whose irreverence was rebuked by Isaiah, nor let them seem like the impudence of Babylon criticized in the 72nd Psalm.

But let these words be acceptable as were the fragrant offerings

in the tabernacle at Shiloh

raised again by David on his return from captivity

as the resting place for the Ark of the Covenant, a symbol for the restoration of my lost soul.

St. Gregory was a devoted son of the Armenian Church. He believed that the Armenian Church had a special mission and hoped that his book would help deliver that message: "as I was conceived and born in the womb of the Church... I now should address the great and immaculate queen... my glorious mother, so she may be known and proclaimed and the extent of her venerable glory might be told to the nations in the future." Having lost his mother when he was a child, he loved the Church like a mother: "This spiritual, heavenly mother of light cared for me as a son more than an earthly, breathing, physical mother could."

People believed that Narek was a sacred book because of the majestic prayers it contained and believed that even touching the manuscript would cure them from diseases. People initiated long pilgrimages to see Narek, to have a touch of Narek or to pray on Narek. Few books have been as influential as the Narek. People had such a strong faith in Narek, that even the touch of Narek has produced positive results in terms of alleviating pain or curing. Numerous examples of curing with Narek are registered historically (Davtyan 2012).

Many scholars think, that if a book similar to Narek was written by any European writer, it would gain universal acceptance even in the Middle Ages. The only reason Narek is not as widely known and read as works of Confucius, Descartes, Hume etc. is because he has written in Armenian, a language that only a handful of people can read.

The Narek is a nicely written book which makes everyone to analyze him/herself and to honestly evaluate his/her behavior and values. It leads 
the person to stand in front of God and in front of his horrible sins against his/her body, his/her spirit, other individuals, the humankind and the Almighty.

Narek is written in Grabar, the ancient Armenian and is a melodic prayer. It was believed that thanks to the fine style of its lines, it has gained even more power in leading people towards repentance, towards communion with God. Anyone who has read the Narek, will assure that it eventually brings peace, harmony and love onto the reader.

St. Gregory was the son of Bishop Khosrov Andzevatsi. He was from a family of scholars at the Monastery of Narek, on the south-eastern shore of Lake Van, near his birthplace, home to the magnificent, newly built 10th-century island cathedral of Aghtamar. He grew up in an atmosphere infused with ritual and Bible. Born in 951 shortly before the first millennium of Christianity, he followed his father and his uncle, the Abbot Anania, into Narek Monastery as did his brother Hovhannes, who later helped St. Gregory with the Book of Prayer. Abbot Anania was an original thinker and teacher, the founder and one of the pillars of Armenian mysticism.

His father and uncle earned the ire of the church hierarchy for being independent thinkers. According to some commentators, these views may have implicated them in certain doctrinal disputes, which St. Gregory had to wrestle with throughout his life. Church tradition relates that, in his old age, he was called before a religious tribunal to defend his adherence to accepted doctrine. On this occasion he prepared a work, called the Root of Faith, once thought lost, but which appears to have been preserved in five doctrinal prayers of the Narek.

The reverence for St. Gregory was already evident in his life time and his sainthood was recognized by his contemporaries. He is referred to as St. Gregory in the earliest extant manuscript of the Book of Prayer, copied and illuminated by the scribe and miniaturist Gregor Skevratsi, containing a hagiography of St. Gregory written by St. Nerses
Lambronatsi (1153-1198). During his own life, he was looked upon as a great teacher:

"I was dubbed, 'Master,' which testifies against me. I was called, 'Teacher, teacher,' in the manner of the saintly, his unworthiness was ever before him: "There is another ache in my heart, for they consider me to be something I am not." He was uncomfortable with this reverence: "I was called by the highest names, but by my works I earned the worst of these descriptions" (Narek of Grigor 2003).

Narekatsi searched the human perfectness in the perfect faith in God and suffered greatly for his "poor faith" in the Almighty:

Look with mercy upon me in my doubts and perils,

glorified Son of God, who alone are compassionate

and will pardon, heal, save, protect, renew, restore,

lift up, support,

and create me again in blissful purity.

The idea of curing from diseases is mentioned in Narek numerous times. However, Narek and its curing methods are not comparable to today's scientific curing methods, its results are not comparable to the results achieved by any contemporary medical institution. These methods are in two different spheres of culture and are used for two different types of diseases: one for spiritual diseases, the other for bodily ones. Thus these curing methods are better to consider complementary rather than contradictory (Davtyan 2013 ${ }^{\text {b }}$.

Narekatsi claims that he has written this text for curing the ills of body and soul: And may you make this book of mournful psalms begun in your name, Most High, into a life-giving salve for the sufferings of body and soul. (Prayer 3, E).

Narek offers mainly spiritual remedy. Its powers, as believed from early Middle Ages, was based on the power of the Word and Will of God. In all cases, when Narek suggests using a physical item for remedy it is a symbolic item, e.g. the Right Hand. 
Gregor of Narek relates sins and diseases. According to Narek, human diseases are a result of human sins. Sins force people to live with a life not naturally designed for human beings. For example, adultery, avarice etc. are forms of behavior that are not natural to human beings. Thus when a person sins, he/she starts to behave in a way for which the human body is not designed for and thus the body gets ill.

Because both sins and diseases are caused by breaking the Divine law, they both can be overcome by repentance. The will, the decision to repent brings relief on the human being. But it does not happen all at once, the relief from pains comes during time and it may take long.

In Narek first the sinful character of humans is depicted. Gregor of Narek undertakes the whole responsibility for all sins committed by all human beings at all times and thus demonstrates the need for curing the mankind. In order the mankind and individuals to be cured humans need to first conceive their sins. Once the sin is conceived the person needs to repent and later to suffer for sins as the Almighty decides.

Narekatsi moves forward, in addition to depicting the vast majority of human sins and thus discovering the true nature of human psyche (I think no other writer or thinker has ever so well pictured the true nature of human psyche), he reveals the way for salvation. Narek is first of all a way for salvation.

It is through this way of salvation, that the complexity and severity of his sins are revealed.

\section{REFERENCES}

Narekaci S.G. (1970). Matyan voghbergut'yan (Book of Lamentations). Yerevan: Hayastan hratarakchut'yun, p. 126.

Davtyan S.H. (2013 $)$. Xosqabanut'yan socialp'ilisop'ayakan himqery' Nareki o'rinakov (The Social-Philosophical Background of Curing with Words (Narekatsi)). Yerevan:
And these sins include the lack of true faith, negative human passions, unhealthy social settings etc. On the other hand, Narek also pictures the positive aspects of human being: aspiration towards light, desire to have freedom, to clean and improve one's own spirit.

Narekatsi, being a Christian monk, based his book, the Narek on the Bible, because he believed no other book could be the bases for wisdom, genius, moral perfection and aesthetic joy, for fortification of will and attainment of eternal hope, for attainment of freedom and for clearing sins, for multiplying graces and freeing oneself from vices.

Narekatsi claims that the non-objective, the word and will of God can be objectified, that is to get body and heaviness. Throughout his prayers he makes the same claim over and over again. All that happens in this word is simply objectification of divine word and will (Davtyan 2013 ${ }^{\mathrm{a}}$ ).

There can also be non-physical, non-objective pain, that of the sin. When someone sins, he/she is hurt already and it eventually causes physical harm. Curing the physical damage of the body does not heal the person as a whole. Only the moral courage, the courage to repent and ask for forgiveness heals the person and cleans the person from sins. Thus, according to Narekatsi, diseases are nothing else but objectification of the non-objective, the will of God, the word of God, and to cure a disease, one needs not only physical means, but also nonobjective, non-physical remedies such as repentance.

the Collection of Scientific Articles of YSMU RA annual conference, volume II, Yerevan: $\mathrm{HH}, \mathrm{EPBH}$ Tarekan hashvetu gitajhoghov, Gitakan hodvac'neri jhoghovac'u, hator II, pp. 335-342.

Petrosyan A. (2002). Nareky' bjhshkaran (Narek as a Remedy), Berd'or. 
Narekatsi S.Gr.(2003): Matean voghbergut'ean \& ayl erkasirut'iwn (Book of Lamentation and other works), Lebanon, Ant'ilias.

Davtyan S.H. (2012). The Use of Works of Medieval Armenian Thinkers in Teaching Bioethics: "Narek" As a Remedy. In the Book of Abstracts: Bioethics Education: Contents,
Methods, Trends, Tiberias, Israel, pp. 5253.

Davtyan S.H. $\left(2013^{\mathrm{b}}\right)$. Bioethics. Word Curing and Music Therapy, In the Book of Abstracts of the UNESCO Chair in Bioethics 9th World Conference on Bioethics, Medical Ethics and Health Law, Naples, Italy, pp. 52-53. 